\title{
Determination of multi-element profiles of street dust using energy dispersive X-ray fluorescence (EDXRF)
}

\author{
Z.L.L. Yeung ${ }^{\mathrm{a}}$, R.C.W. Kwok ${ }^{\mathrm{b}}$, K.N. Yu ${ }^{\mathrm{a}, *}$ \\ ${ }^{a}$ Department of Physics and Materials Science, City University of Hong Kong, Tat Chee Avenue, \\ Kowloon Tong, Kowloon, Hong Kong \\ ${ }^{\mathrm{b}}$ Department of Public and Social Administration, City University of Hong Kong, Tat Chee Avenue, \\ Kowloon Tong, Kowloon, Hong Kong
}

Received 21 August 2002; received in revised form 15 October 2002; accepted 2 December 2002

\begin{abstract}
Street dust samples have been collected in different areas in Hong Kong associated with various levels of traffic and pedestrian flow, and the concentrations of 23 chemical elements have been determined using energy dispersive X-ray fluorescence (EDXRF). The 23 studied elements were $\mathrm{Na}, \mathrm{Al}, \mathrm{Si}, \mathrm{Cl}, \mathrm{Ti}, \mathrm{Ba}, \mathrm{V}, \mathrm{Cr}, \mathrm{Mn}, \mathrm{Fe}, \mathrm{Co}, \mathrm{K}$, $\mathrm{Ca}, \mathrm{Ni}, \mathrm{Cu}, \mathrm{Zn}, \mathrm{As}, \mathrm{Pb}, \mathrm{Rb}, \mathrm{Sr}, \mathrm{Y}, \mathrm{Zr}$ and $\mathrm{Sn}$. A profile for average street dust for Hong Kong has been determined by taking average values for different areas. The values for the Hong Kong street dust are commensurate with the values derived in previous investigations or for other countries, except that Hong Kong street dust has much higher $\mathrm{Cl}, \mathrm{Ca}$ and As concentrations. A factor analysis gives four sources for the street dust in Hong Kong: namely, mixture of metallic dust and crustal material, vehicles, road pavement materials, and mixture of marine aerosols and crustal material.
\end{abstract}

(C) 2003 Elsevier Science Ltd. All rights reserved.

Keywords: Energy dispersive X-ray fluorescence; EDXRF; Dust; Profiles

\section{Introduction}

The multi-element source profile for street dust for an area can be used to characterize the heavy metal contamination from atmospheric deposition and to help quantify the contribution from street dust to the air pollutants in an area through the chemical mass balance (CMB) method. Notwithstanding the identifications of high concentrations of anthropogenic aerosols in Hong Kong and the growing concern about the air pollution issue in Hong Kong in recent years, there are still controversies over the main air pollutant sources in various highly polluted areas. The CMB method is most appropriate for this

\footnotetext{
*Corresponding author. Tel.: +852-2788-7812; fax: +8522788-7830.

E-mail address: peter.yu@cityu.edu.hk (K.N. Yu).
}

kind of source apportionment, but the crucial step is the determination of the composition of material emitted by a variety of local air pollution sources (or source profiles).

Source profiles of air pollutants have been compiled and are widely used in source apportionment studies (e.g., see references in Watson et al., 2001). Notwithstanding, source profiles for different air pollutant sources are still unavailable for Hong Kong. Unfortunately, as commented by Watson et al. (2001), the profiles differ with respect to location and time, so the source profiles cannot be simply borrowed from studies elsewhere and the sources of air pollutants in Hong Kong cannot be identified through the CMB method. One of the major sources of outdoor air pollutants is the street dust. The present work is devoted to experimentally determining the source profiles of street dust in Hong Kong. Possible sources of street dust will also be identified. 


\section{Methodology}

\subsection{Sample collection and preparation}

Street dust samples have been collected from eight selected places in Hong Kong, namely, Mong Kok, Tai Po, Causeway Bay, Central, Kowloon Tong, Tai Wai, Quarry Bay, and the car park of City University of Hong Kong. All the samples were collected in October and November 2001. Descriptions of these eight sites are given in Table 1, and a map showing the locations of these sites is shown in Fig. 1. The samples were collected using a plastic brush and tray. More than $3 \mathrm{~g}$ of street dust was collected from each site. After shipment back to the laboratory, these samples were individually dried to constant weight in an oven at about $60^{\circ} \mathrm{C}$ (for more than $24 \mathrm{~h}$ ).

The street dust samples were first sieved through an $86 \mu \mathrm{m}$ mesh. The analyses were restricted to the size fraction below $100 \mu \mathrm{m}$ since these particles can be transported by suspension, in contrary to the saltation for particles between 100 and $500 \mu \mathrm{m}$ or creep for particles between 500 and $1000 \mu \mathrm{m}$ (Schmel, 1980; Nicholson, 1988; de Miguel et al., 1997). About $3 \mathrm{~g}$ of street dust was used for each sample. The dust was homogenized and then pressed into stable pellets using SpectroPress ${ }^{\circledR}$ Systems (Model no.: Automatic 50 ton PRESS, Chemplex Industries, Inc., USA) with die diameter of $32 \mathrm{~mm}$ and the following settings: force $=30$ ton, dwell time $=3 \mathrm{~min}$ and bleed time $=$ $4 \mathrm{~min}$. Two replicate dust samples were prepared for each site except those for Mong Kok and Tai Po, which had three replicate samples.

\subsection{Energy dispersive $X$-ray fluorescence}

The elemental concentrations were determined using energy dispersive X-ray fluorescence (EDXRF). EDXRF provides a rapid and non-destructive method for the analysis of trace and major elements in street dust samples. All measurements were carried out under the vacuum condition, using an EDAX International DX-95 EDXRF spectrometer with a Mo target, equipped with a liquid- nitrogen-cooled $\mathrm{Si}(\mathrm{Li})$ detector. The incident and take-off angles were $45^{\circ}$, with a Be window thickness of $12.5 \mu \mathrm{m}$. The distance between the sample (exposed diameter of $22 \mathrm{~mm}$ ) and the detector was $4.5 \mathrm{~cm}$. The energy resolution was $0.16 \mathrm{keV}$. We measured the concentrations of 23 chemical elements: namely, $\mathrm{Na}, \mathrm{Al}, \mathrm{Si}, \mathrm{Cl}, \mathrm{Ti}, \mathrm{Ba}, \mathrm{V}, \mathrm{Cr}, \mathrm{Mn}, \mathrm{Fe}, \mathrm{Co}, \mathrm{K}, \mathrm{Ca}$, $\mathrm{Ni}, \mathrm{Cu}, \mathrm{Zn}, \mathrm{As}, \mathrm{Pb}, \mathrm{Rb}, \mathrm{Sr}, \mathrm{Y}, \mathrm{Zr}$ and $\mathrm{Sn}$.

In order to maximize the EDXRF sensitivities for the wide range of elements in which we were interested, four different combinations of EDXRF parameters (including voltage and current) and X-ray filters were employed for different elements for each street dust sample, as
Table 1

Description of the sites from which the street dust samples were obtained

\begin{tabular}{ll}
\hline Mong Kok & Mixed commercial and residential area \\
Many vehicles: trucks, taxis and vans, but \\
no buses \\
No trees \\
No soils around \\
Many pedestrians \\
Residential area \\
Only buses \\
No trees \\
Little gravels or soils around \\
Few pedestrians \\
Busy commercial area \\
Many vehicles: buses, taxis, trucks, trams \\
and vans \\
No trees \\
No soils around \\
Many pedestrians
\end{tabular}

Central Busy commercial area

Many vehicles: buses, taxis, trucks, trams and vans

Trees around

Small amount of soil around

Many pedestrians

Kowloon Tong Residential area

Some vehicles: buses, trucks, taxis and mini-buses

Trees around

Small amount of soil around

Few pedestrians

Tai Wai

Residential area

Some vehicles: mini-buses, taxis, vans and trucks

Trees around

Soil around

Few pedestrians

Quarry Bay Mixed commercial and residential area Many vehicles: mini-buses, taxis, vans, trucks and buses

No trees

No soils around

Many pedestrians

Car park Only cars and vans

No trees

Small amount of soil around

Few pedestrians

shown in Table 2. The EDXRF $\mathrm{K} \alpha$ line intensities were measured for all elements except $\mathrm{Pb}$, for which the $\mathrm{L} \alpha$ line intensities were measured. For better efficiencies, the 


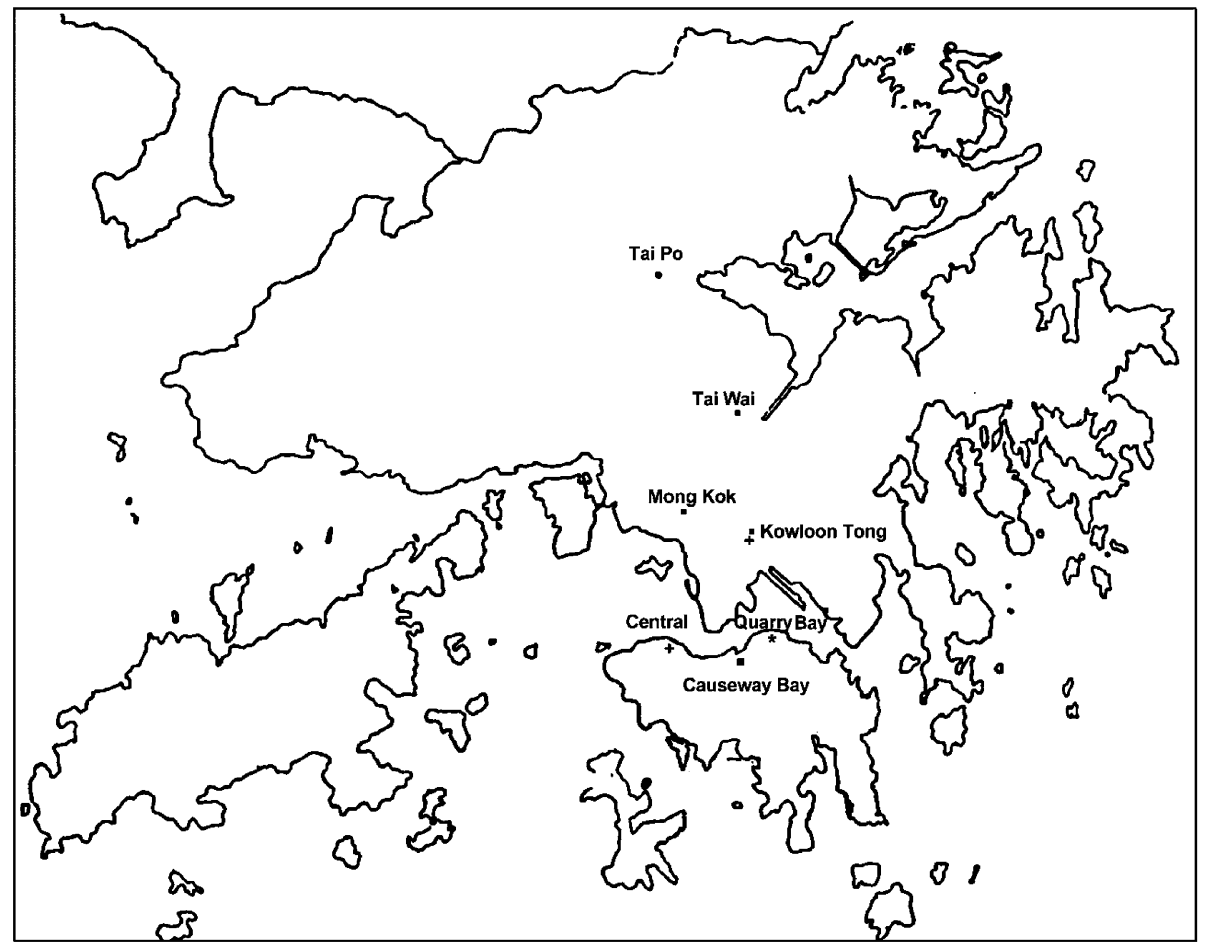

Fig. 1. A map showing the locations of the eight sites from which street dust samples were collected for the present determination of multi-element profiles of street dust. City University of Hong Kong is also in the area of Kowloon Tong.

Table 2

Combinations of EDXRF parameters and X-ray filters employed for different studied chemical elements

\begin{tabular}{llll}
\hline Elements & Voltage $(\mathrm{kV})$ & Current $(\mu \mathrm{A})$ & X-ray filter \\
\hline $\mathrm{Na}, \mathrm{Al}, \mathrm{Si}$ & 10 & 500 & Nil \\
$\mathrm{Cl}$ & 15 & 160 & Nil \\
$\mathrm{Ti}, \mathrm{Ba}, \mathrm{V}, \mathrm{Cr}, \mathrm{Mn}, \mathrm{Fe}, \mathrm{Co}, \mathrm{K}, \mathrm{Ca}$ & 25 & 35 & Nil \\
$\mathrm{Ni}, \mathrm{Cu}, \mathrm{Zn}, \mathrm{As}, \mathrm{Pb}, \mathrm{Rb}, \mathrm{Sr}, \mathrm{Y}, \mathrm{Zr}, \mathrm{Sn}$ & 50 & 70 & $\mathrm{Mo}$ \\
\hline
\end{tabular}

applied voltage increased in general with the required $\mathrm{K} \alpha$ or $\mathrm{L} \alpha$ line energies. The current was adjusted to maintain similar portions of live detection time. The Xray filters were used for particular line energies to reduce the relevant background intensities.

\subsection{Calibration}

Concentrations for the chemical elements are required in the present study, so extra calibration steps have to be taken to provide conversions of the EDXRF intensities into concentrations of the chemical elements. Soil reference materials, namely, GBW07403, GBW07404, GBW07406 and GBW07410, purchased from the Institute of Marine Geology, National Research Center for Certified Reference Materials, People's Republic of China, were employed as bases of our calibration sources. For some calibration sources, additional chemicals were added to cover the ranges encountered in our street dust samples. Nine chemicals were used, including $\mathrm{KCl} \quad(99.995 \%$, from Johnson Matthey, \#87626), $\mathrm{NaCl}(99.999 \%$, from Johnson Matthey, \#6312904), $\mathrm{CaCl}_{2}$ (95\%, from Riedel-de Haën $\left.{ }^{\circledR}, \# 12021\right), \quad \mathrm{CaO}(99.9995 \%$, from Johnson Matthey, \#20979), ZnO (99.999\%, from ACROS, \#AO11070001), $\mathrm{Y}_{2} \mathrm{O}_{3}(99.99 \%$, from Aldrich Chemical, \#20516-8), $\mathrm{ZrOCl}_{2} \cdot 8 \mathrm{H}_{2} \mathrm{O}$ (99.9985\%, from Strem Chemicals, Inc., \#40-2500), RbCl (99.8+\%, from ACROS, \#AC201260100), and $\mathrm{SnCl}_{2} \cdot 2 \mathrm{H}_{2} \mathrm{O}$ (China National Chemicals Import \& Export Corporation, Peking Branch). A blender (from Chemplex ${ }^{\circledR}$, \#600) was also added in some cases for better binding properties. The reference materials were homogenized and pressed into pellets using SpectroPress ${ }^{\mathbb{B}}$ Systems as mentioned above 
with the same settings: force $=30$ ton, dwell time $=3 \mathrm{~min}$ and bleed time $=4 \mathrm{~min}$.

\subsection{Factor analysis ( $F A)$}

FA has been applied to the obtained EDXRF data in an attempt to identify sources of street dust. Principal component analysis (PCA) was first applied to determine the number of sources and to establish the provisional factors. The crucial part of the PCA is the transformation of the original sample covariance matrix $\mathbf{S}$ (or the correlation matrix) by a rotation of the coordinate system. For a $p$-variable problem,

$\mathbf{S}=\left[\begin{array}{cccc}s_{1}^{2} & s_{12} & \cdots & s_{1 p} \\ s_{12} & s_{2}^{2} & \cdots & s_{2 p} \\ \vdots & \vdots & & \vdots \\ s_{1 p} & s_{2 p} & \cdots & s_{p}^{2}\end{array}\right]$

where $s_{i}^{2}$ is the variance of the $i$ th variable $x_{i}$, and $s_{i j}$ is the covariance between the $i$ th and the $j$ th variables. A non-zero covariance between two variables indicates a linear relationship between them, the strength of which being represented by the correlation coefficient, $r_{i j}=$ $s_{i j} /\left(s_{i} s_{j}\right)$. A rotation of the coordinate system transforms $\mathbf{S}$ to $\mathbf{L}=\mathbf{U}^{\prime} \mathbf{S U}$, where $\mathbf{U}$ is the matrix of direction cosines employed in the transformation. The objective is to find a rotated coordinate system such that all covariances in $\mathbf{L}$ become zero. This becomes an eigenvalue problem.

This rotation will transform the $p$ originally correlated variables $X_{1}, X_{2}, \ldots, X_{p}$ into $p$ new uncorrelated indices $Z_{1}, Z_{2}, \ldots, Z_{p}$. The coordinate axes of these new indices are described by the eigenvectors $\mathbf{u}_{i}$ which make up the matrix $\mathbf{U}$. The $i$ th eigenvalue, which is transformed from $s_{i}^{2}$ and which is the $i$ th element in the diagonal matrix $\mathbf{L}$, is therefore the variance of $Z_{i}$.

When one performs a PCA, there is always a hope that the variances of the original variables $X$ are effectively captured by a few $Z$ indices, and that most other $Z$ 's will have very low variances and will become negligible. Under such circumstances, the variation in the original data set can be adequately described by those few $Z$ variables (called principal components or PCs) with variances that are not negligible, with the first PC capturing the largest possible variances from the original variables, and the second one capturing the largest possible variances left over by the first one, and so on.

In normal FAs, only PCs with eigenvalues greater than one will be retained, which is called the Kaiser criterion, and these form our provisional factors. A further rotation in the factor space is needed to transform the provisional factors in order to find the new factors that are easier to interpret. Various rotational strategies have been proposed. One commonly used traditional strategy is called the varimax rotation, which will be employed in the present work.

\section{Results and discussion}

The concentrations for the 23 elements (in $\mathrm{mg} / \mathrm{kg}$ ) are shown in Table 3. From Table 1, we can see that, within the eight sites, Tai Po (TP), Kowloon Tong (KT) and Tai Wai (TW) are the sites with relatively smaller traffic and pedestrian volumes. Interestingly, the concentrations of some chemical elements seem to have relationship with these volumes. For example, the concentrations of $\mathrm{Ti}, \mathrm{Ba}, \mathrm{Cr}, \mathrm{Fe}, \mathrm{Co}, \mathrm{Cu}$ and $\mathrm{Pb}$ are low in TW, KT and TP, which might suggest the anthropogenic nature of these elements. On the other hand, the concentrations of $\mathrm{Al}$ and $\mathrm{Y}$ are high in TW, KT and TP, which suggest that these elements mainly come from natural sources. The dust collected from the car park of City University of Hong Kong (CP) has highest concentrations for the elements $\mathrm{Ba}, \mathrm{Cu}, \mathrm{Zn}$ and $\mathrm{Pb}$ among all the samples, which suggests that these elements are likely to originate from vehicles.

A profile for the average street dust for Hong Kong is calculated by taking average values for these eight sites. The concentrations for the 23 elements for this average Hong Kong street dust have also been shown in Table 3. The source profiles of street dust obtained in previous investigations and for other countries are also shown together with the source profile of the Hong Kong street dust derived in the present work in Table 4. The values for the Hong Kong street dust are commensurate with the values derived by other workers except that Hong Kong street dust has much higher $\mathrm{Cl}, \mathrm{Ca}$ and $\mathrm{As}$ concentrations. In particular, the abundance of $\mathrm{Cl}, \mathrm{Ca}$ and $\mathrm{As}$ in the average Hong Kong street dust are $2.49 \%$, $19.9 \%$ and $0.0067 \%$. The reason behind the exceptionally high concentrations of $\mathrm{Cl}$ is not clear, and might be due to organic compounds. The contents of $\mathrm{Cu}, \mathrm{Zn}$ and $\mathrm{Pb}$ have also been determined for street dust in Hong Kong by Li et al. (2001). The average values obtained in the present work, viz., 110,3840 and $120 \mathrm{mg} / \mathrm{kg}$ for $\mathrm{Cu}$, $\mathrm{Zn}$ and $\mathrm{Pb}$, respectively, are consistent with those obtained by $\mathrm{Li}$ et al. (2001), viz., 173, 1450 and $181 \mathrm{mg} / \mathrm{kg}$, respectively.

The PCA for our data gave six PCs with eigenvalues (which are equivalent to the variances of the corresponding PCs, see above) greater than one. In normal FAs, only PCs with eigenvalues greater than one will be retained, which is called the Kaiser criterion. The eigenvalues for the first six PCs are 8.67, 4.61, 3.28, $2.44,2.10$ and 1.50, respectively. The six sources were then obtained through an orthogonal varimax rotation of the six provisional factors, with the factor loadings shown in Table 5. Although some sources can be inferred from the factor loadings shown in Table 5, the 
Table 3

Total element concentrations $(\mathrm{mg} / \mathrm{kg})$ in street dust in Hong Kong

\begin{tabular}{|c|c|c|c|c|c|c|c|c|c|}
\hline & MK & TP & $\mathrm{CB}$ & $\mathrm{C}$ & KT & TW & QB & $\mathrm{CP}$ & Mean \\
\hline $\mathrm{Na}$ & 3500 & 2740 & 4980 & 3760 & 3660 & 6080 & 3320 & 4290 & $4040 \pm 410$ \\
\hline $\mathrm{Al}$ & 13900 & 24100 & 16500 & 18000 & 25700 & 23400 & 22000 & 19900 & $20400 \pm 1100$ \\
\hline $\mathrm{Si}$ & 158000 & 211000 & 202000 & 237000 & 204000 & 224000 & 213000 & 185000 & $204000 \pm 4000$ \\
\hline $\mathrm{Cl}$ & 53000 & 7820 & 29200 & 17200 & 23600 & 29600 & 20000 & 18400 & $24900 \pm 900$ \\
\hline $\mathrm{Ti}$ & 2970 & 2340 & 2120 & 1870 & 1850 & 1790 & 2400 & 3660 & $2370 \pm 50$ \\
\hline $\mathrm{Ba}$ & 299 & 126 & 334 & 189 & 185 & 173 & 210 & 507 & $253 \pm 20$ \\
\hline $\mathrm{V}$ & 46.0 & 37.5 & 42.1 & 26.4 & 42.1 & 32.9 & 14.5 & 51.5 & $36.6 \pm 2.4$ \\
\hline $\mathrm{Cr}$ & 177 & 65.7 & 147 & 156 & 138 & 90.4 & 117 & 106 & $124 \pm 7$ \\
\hline $\mathrm{Mn}$ & 512 & 664 & 615 & 646 & 591 & 558 & 579 & 589 & $594 \pm 14$ \\
\hline $\mathrm{Fe}$ & 14100 & 12500 & 15700 & 18400 & 11200 & 10200 & 15300 & 15400 & $14100 \pm 50$ \\
\hline $\mathrm{Co}$ & 10.5 & 9.22 & 8.84 & 14.1 & 4.62 & 5.43 & 12.4 & 11.1 & $9.52 \pm 0.58$ \\
\hline K & 14100 & 10600 & 15100 & 11000 & 11900 & 14200 & 11600 & 12800 & $12700 \pm 700$ \\
\hline $\mathrm{Ca}$ & 287000 & 253000 & 227000 & 172000 & 136000 & 133000 & 165000 & 223000 & $199000 \pm 6000$ \\
\hline $\mathrm{Ni}$ & 30.6 & 19.8 & 19.7 & 29.3 & 46.2 & 14.0 & 30.6 & 38.8 & $28.6 \pm 5.2$ \\
\hline $\mathrm{Cu}$ & 133 & 40.9 & 127 & 134 & 71.9 & 53.4 & 129 & 190 & $110 \pm 4$ \\
\hline $\mathrm{Zn}$ & 4860 & 3510 & 3500 & 2250 & 2920 & 3510 & 3800 & 6380 & $3840 \pm 70$ \\
\hline As & 47.3 & 83.6 & BDL & 44.0 & BDL & 119 & 40.6 & BDL & $66.8 \pm 5.7$ \\
\hline $\mathrm{Pb}$ & 130 & 102 & 114 & 96.2 & 86.0 & 92.1 & 150 & 191 & $120 \pm 4$ \\
\hline $\mathrm{Rb}$ & 89.1 & 153 & 154 & 148 & 256 & 330 & 201 & 163 & $187 \pm 7$ \\
\hline $\mathrm{Sr}$ & 144 & 153 & 124 & 107 & 95.8 & 92.4 & 105 & 148 & $121 \pm 3$ \\
\hline $\mathrm{Y}$ & 22.7 & 52.4 & 30.6 & 28.5 & 66.0 & 61.6 & 46.4 & 39.3 & $43.4 \pm 1.8$ \\
\hline $\mathrm{Zr}$ & 180 & 250 & 395 & 939 & 380 & 306 & 386 & 188 & $378 \pm 15$ \\
\hline Sn & 251 & 25.2 & 228 & 72.3 & 136 & 1140 & 1540 & 139 & $442 \pm 30$ \\
\hline
\end{tabular}

MK: Mong Kok; TP: Tai Po; CB: Causeway Bay; C: Central; KT: Kowloon Tong; TW: Tai Wai; QB: Quarry Bay; CP: Car park of City University of Hong Kong.

BDL: Below Detection Limit.

interpretation will be clearer if we extract fewer sources. In particular, we find that the interpretations will be best if we reduce the number of sources to four, the factor loadings of which are shown in Table 6. In comparison, De Miguel et al. (1997) also made use of the concentrations of 22 chemical elements of 38 samples to identify three sources for the street dust in Madrid (Spain) and Oslo (Norway).

The first source in Table 6 points to a mixture of metallic dust and crustal material. In particular, stainless steel and alloy steel contain $\mathrm{Fe}, \mathrm{Cr}$, $\mathrm{Co}$ and/or $\mathrm{Cu}$. It is also noted that Co does not exist in Hong Kong soil ( $\mathrm{Yu}$ et al., 2002). Al, Rb and $\mathrm{Y}$ characterize crustal material. The negative factor loadings for these elements mean that when there is a significant input of this source to the samples, there are decreased concentrations of $\mathrm{Al}, \mathrm{Rb}$ and $\mathrm{Y}$, or alternatively, there are increased concentrations of steel metals. In other words, there is an anticorrelation between the steel component and the crustal material component in this factor. The factor loading for As is only -0.51 so the anti-correlation with As is not significant.

The second source involves the elements $\mathrm{Ti}, \mathrm{Ba}, \mathrm{Ni}$, $\mathrm{Cu}, \mathrm{Zn}$ and $\mathrm{Pb}$. Again, the factor loading for $\mathrm{As}$ is -0.51 so the anti-correlation with As is not significant. This source is clearly due to vehicles. Incidentally, de Miguel et al. (1997) also identified a similar origin as their first source, which involved $\mathrm{Ti}, \mathrm{Ba}, \mathrm{Cu}, \mathrm{Zn}, \mathrm{Pb}, \mathrm{Ca}, \mathrm{Co}, \mathrm{Mg}$ and Mo (the last two elements were not used in our analyses). This source was referred by de Miguel et al. (1997) as the "urban factor".

Ba dispersions are widely used as detergents/dispersants and oxidation and corrosion inhibitors in lubricating oils for diesel and other combustion engines, and as smoke suppressant additives in diesel fuels (De Miguel et al., 1997). The highly basic Ba dispersions which have been used as smoke suppressant additives contain large amounts (e.g., about 20\%) of Ba compounds (De Miguel et al., 1997). Kowalczyk et al. (1978) analysed 27 chemical elements in total suspended particulate samples collected at four sites in Washington, DC, and identified a source attributed to motor vehicles characterized by $\mathrm{Pb}, \mathrm{Br}$ and $\mathrm{Ba}$. De Miguel et al. (1997) also commented that the influence of traffic is characterized by $\mathrm{Zn}$ and $\mathrm{Ba}$, and to a lesser extent by $\mathrm{Cu}$ and $\mathrm{Pb}$. $\mathrm{Zn}$ and $\mathrm{Ba}$ are highly correlated in the street dust of Oslo and both can be traced back to automobiles (Kowalczyk et al., 1982).

Exhaust emissions from both gasoline- and dieselfuelled road vehicles contain variable quantities of $\mathrm{Cu}$ 
Table 4

Source profiles of street dust $(\mathrm{mg} / \mathrm{kg}$ or $\mu \mathrm{g} / \mathrm{g})$ as derived in the present work and those in other investigations

\begin{tabular}{|c|c|c|c|c|c|c|c|}
\hline & $\begin{array}{l}\text { Present } \\
\text { work } \\
(2002)\end{array}$ & $\begin{array}{l}\text { Li et al. } \\
(2001) \\
\text { (Hong Kong) }\end{array}$ & $\begin{array}{l}\text { Fergusson and } \\
\text { Ryan (1984) } \\
\text { (London) }\end{array}$ & $\begin{array}{l}\text { Fergusson et al. } \\
(1986) \\
\text { (New Zealand) }\end{array}$ & $\begin{array}{l}\text { De Miguel } \\
\text { et al. (1997) } \\
\text { (Oslo) }\end{array}$ & $\begin{array}{l}\text { De Miguel } \\
\text { et al. (1997) } \\
\text { (Madrid) }\end{array}$ & $\begin{array}{l}\text { Rasmussen } \\
\text { et al. (2001) } \\
\text { (Ottawa) }\end{array}$ \\
\hline $\mathrm{Na}$ & 4040 & & 2757 & 17300 & 19295 & & 18273 \\
\hline $\mathrm{Al}$ & 20400 & & 15500 & 48400 & 59527 & 43800 & 47540 \\
\hline $\mathrm{Si}$ & 204000 & & 165000 & & & & \\
\hline $\mathrm{Cl}$ & 24900 & & 538 & 381 & & & \\
\hline $\mathrm{Ti}$ & 2370 & & 1465 & 2117 & 7452 & 1100 & \\
\hline $\mathrm{Ba}$ & 253 & & & & 526 & & 576 \\
\hline $\mathrm{V}$ & 36.6 & & 80 & 58.3 & & 17 & 34 \\
\hline $\mathrm{Cr}$ & 124 & & 112 & 103 & & 61 & 43.3 \\
\hline $\mathrm{Mn}$ & 594 & & 379 & 313 & 833 & 362 & 431.5 \\
\hline $\mathrm{Fe}$ & 14100 & & 22800 & 20900 & 51452 & 19300 & 18948 \\
\hline $\mathrm{Co}$ & 9.52 & & 7.3 & 6.41 & 19 & 3 & 8.31 \\
\hline $\mathrm{K}$ & 12700 & & 4181 & 18300 & & & 14963 \\
\hline $\mathrm{Ca}$ & 199000 & & 21000 & 8200 & 42691 & & 96787 \\
\hline $\mathrm{Ni}$ & 28.6 & & & & 41 & 44 & 15.2 \\
\hline $\mathrm{Cu}$ & 110 & 173 & 191 & 90.8 & 123 & 188 & 65.84 \\
\hline $\mathrm{Zn}$ & 3840 & 1450 & 1176 & 716 & 412 & 476 & 112.5 \\
\hline As & 66.8 & & 27 & 14.5 & & & 1.3 \\
\hline $\mathrm{Pb}$ & 120 & 181 & 2008 & 1223 & 180 & 1927 & 39.05 \\
\hline $\mathrm{Rb}$ & 187 & & & & 65 & & 37.2 \\
\hline $\mathrm{Sr}$ & 121 & & & & 344 & & 459 \\
\hline $\mathrm{Y}$ & 43.4 & & & & 24 & & \\
\hline $\mathrm{Zr}$ & 378 & & & & & & \\
\hline $\mathrm{Sn}$ & 442 & & & & & & 3.02 \\
\hline
\end{tabular}

Table 5

Rotated factor loadings for the six sources of street dust (only those larger than 0.5 are shown)

\begin{tabular}{|c|c|c|c|c|c|c|}
\hline & 1 & 2 & 3 & 4 & 5 & 6 \\
\hline $\mathrm{Na}$ & & & & & & 0.94 \\
\hline $\mathrm{Al}$ & & -0.79 & -0.52 & & & \\
\hline $\mathrm{Si}$ & -0.59 & & -0.67 & & & \\
\hline $\mathrm{Cl}$ & & & 0.98 & & & \\
\hline $\mathrm{Ti}$ & 0.92 & & & & & \\
\hline $\mathrm{Ba}$ & 0.76 & & & & & \\
\hline $\mathrm{V}$ & & & & 0.80 & & \\
\hline $\mathrm{Cr}$ & & 0.54 & 0.63 & & & \\
\hline $\mathrm{Mn}$ & & & -0.87 & & & \\
\hline $\mathrm{Fe}$ & & 0.95 & & & & \\
\hline $\mathrm{Co}$ & & 0.88 & & & & \\
\hline $\mathrm{K}$ & & & 0.63 & & & 0.69 \\
\hline $\mathrm{Ca}$ & & & & 0.61 & & \\
\hline $\mathrm{Ni}$ & & & & & 0.93 & \\
\hline $\mathrm{Cu}$ & 0.55 & 0.67 & & & & \\
\hline $\mathrm{Zn}$ & 0.97 & & & & & \\
\hline As & & & & & -0.81 & \\
\hline $\mathrm{Pb}$ & 0.92 & & & & & \\
\hline $\mathrm{Rb}$ & & -0.71 & & & & \\
\hline $\mathrm{Sr}$ & 0.61 & & & 0.62 & & \\
\hline $\mathrm{Y}$ & & -0.91 & & & & \\
\hline $\mathrm{Zr}$ & -0.68 & 0.53 & & & & \\
\hline $\mathrm{Sn}$ & & & & -0.92 & & \\
\hline
\end{tabular}

(Pacyna, 1986). Oxidation of lubricating oils upon exposure to air at high temperatures results in the formation of organic compounds which are corrosive to metal. $\mathrm{Cu}$ can be released to the urban environment as a result of wear of the automobile's oil pump or of those metal parts which come into contact with the oil caused by the corrosive action (De Miguel et al., 1997). Another possible source of $\mathrm{Cu}$ particulate comes from the brake pads of vehicles. In relation to these, the associations of the present source with $\mathrm{Ni}$ and $\mathrm{Ti}$ infer that these elements may come from the steel used in the metal parts. As mentioned above, the influence of traffic is characterized by $\mathrm{Zn}$ and $\mathrm{Ba}$, and to a lesser extent by $\mathrm{Cu}$ and $\mathrm{Pb}$ (De Miguel et al., 1997). Hien et al. (2001) commented that the road dust is enriched with trafficrelated elements such as $\mathrm{Cu}$.

$\mathrm{Zn}$ is used as a vulcanization agent in vehicle tyres and tyre wear has been reported to contribute significantly to $\mathrm{Zn}$ in street dust (Friedlander, 1973). The contribution is expected to be even higher in a high temperature subtropical area like Hong Kong due to the higher tyre wearing rate ( $\mathrm{Li}$ et al., 2001). $\mathrm{Pb}$ has been the most reliable tracer of traffic pollution in the past. However, due to the shift from leaded to unleaded petrol as fuel for automobiles in recent years, vehicular exhaust particles may no longer be a major source of $\mathrm{Pb}$ in the 
Table 6

Rotated factor loadings for the four sources of street dust (only those larger than 0.5 are shown)

\begin{tabular}{lrrrr}
\hline & 1 & 2 & 3 & \multicolumn{1}{l}{4} \\
\hline $\mathrm{Na}$ & & & & 0.61 \\
$\mathrm{Al}$ & -0.76 & & -0.61 & -0.50 \\
$\mathrm{Si}$ & & & & 0.53 \\
$\mathrm{Cl}$ & & 0.84 & & \\
$\mathrm{Ti}$ & & & 0.63 & \\
$\mathrm{Ba}$ & & & & \\
$\mathrm{V}$ & & & & \\
$\mathrm{Cr}$ & 0.75 & & & \\
$\mathrm{Mn}$ & & & & \\
$\mathrm{Fe}$ & 0.91 & & & \\
$\mathrm{Co}$ & 0.77 & & & \\
$\mathrm{~K}$ & & & & \\
$\mathrm{Ca}$ & & & & \\
$\mathrm{Ni}$ & & 0.92 & \\
$\mathrm{Cu}$ & 0.64 & 0.74 & & \\
$\mathrm{Zn}$ & & 0.84 & & \\
$\mathrm{As}$ & -0.51 & -0.51 & & \\
$\mathrm{~Pb}$ & & 0.94 & & \\
$\mathrm{Rb}$ & -0.65 & & & \\
$\mathrm{Sr}$ & & & & \\
$\mathrm{Y}$ & -0.85 & & & \\
$\mathrm{Zr}$ & 0.65 & & & \\
$\mathrm{Sn}$ & & & & \\
\hline
\end{tabular}

atmospheric particulates (De Miguel et al., 1997). As mentioned above, the present results for dust in Table 3 also show that the elements $\mathrm{Ba}, \mathrm{Cu}, \mathrm{Zn}$ and $\mathrm{Pb}$ are likely to originate from vehicles. Li et al. (2001) also observed elevated concentrations of $\mathrm{Cu}, \mathrm{Pb}$ and $\mathrm{Zn}$ in street dust in Hong Kong.

The third source is likely to be road pavement materials. Ca characterizes the cement dust, while the other elements (except $\mathrm{V}$ and $\mathrm{Sn}$ ) characterizes clay and sand. V is normally regarded as a marker for fuel oil or petroleum burning. However, vanadium salts are naturally present in most clay. Moreover, there have been indications that, in the process of cement manufacturing, some $\mathrm{V}$ from the fuel can find its way into the process output materials, clinker and kiln dust. A piece of concrete typical of those used in Hong Kong is shown in Fig. 2. It can be seen that V does exist in the concrete. The reason behind the presence of $\mathrm{Sn}$ is less clear, and its origin needs further exploration. The fourth source is clearly due to the marine aerosols, and some mixture with crustal material.

\section{Conclusions}

(1) Street dust associated with different traffic flow have been sampled, and the concentrations of 23

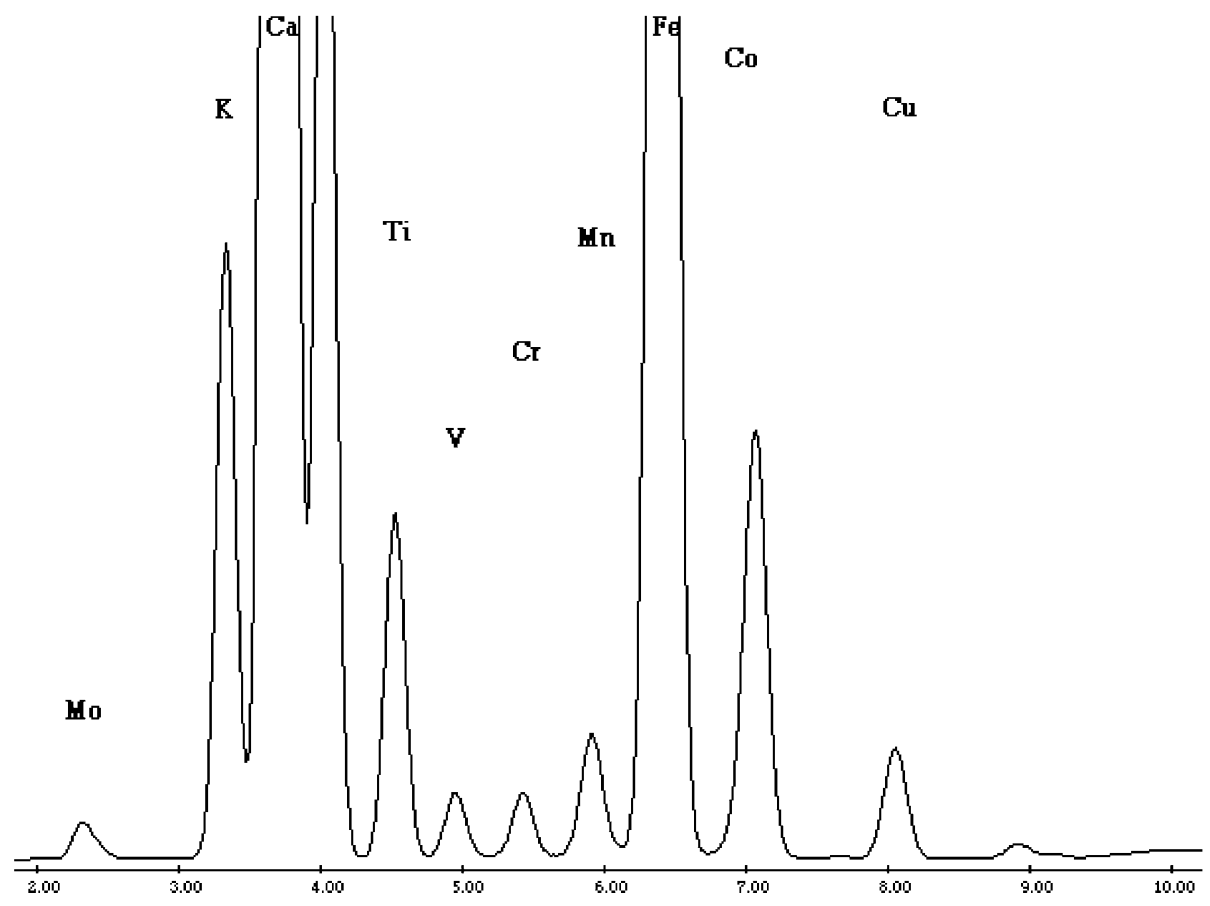

Fig. 2. An EDXRF spectrum of a piece of concrete typical of those used in Hong Kong. The $x$-axis represents the energy (keV) while the $y$-axis shows the relative intensities of X-ray fluorescence photons from different elements. 
chemical elements: namely, $\mathrm{Na}, \mathrm{Al}, \mathrm{Si}, \mathrm{Cl}, \mathrm{Ti}, \mathrm{Ba}$, $\mathrm{V}, \mathrm{Cr}, \mathrm{Mn}, \mathrm{Fe}, \mathrm{Co}, \mathrm{K}, \mathrm{Ca}, \mathrm{Ni}, \mathrm{Cu}, \mathrm{Zn}, \mathrm{As}, \mathrm{Pb}, \mathrm{Rb}$, $\mathrm{Sr}, \mathrm{Y}, \mathrm{Zr}$ and $\mathrm{Sn}$, have been determined using energy dispersive $\mathrm{X}$-ray fluorescence. The concentrations for the 23 elements (in $\mathrm{mg} / \mathrm{kg}$ ) have been shown in Table 3.

(2) Most elements for sites with different traffic and pedestrian flow have similar values or are in continuous ranges. However, at sites with relatively lower traffic and pedestrian flow, levels of $\mathrm{Ti}, \mathrm{Ba}$, $\mathrm{Cr}, \mathrm{Fe}, \mathrm{Co}, \mathrm{Cu}$ and $\mathrm{Pb}$ are low, which might suggest the anthropogenic nature of these elements. On the other hand, the concentrations of $\mathrm{Al}$ and $\mathrm{Y}$ are high, which suggests that these elements are natural.

(3) A profile for the average street dust for Hong Kong has been determined by taking average values for the different street dust categories, and shown in Table 4. The values for the Hong Kong street dust are commensurate with the values obtained in previous investigations or for other countries, except that Hong Kong street dust has much higher $\mathrm{Cl}$, $\mathrm{Ca}$ and As concentrations.

(4) A factor analysis gives four sources for the street dust in Hong Kong: (a) mixture of metallic dust and crustal material, characterized by $(\mathrm{Cr}, \mathrm{Fe}, \mathrm{Co}$, $\mathrm{Cu}$ ) and (Al, Rb, Y, Zr); (b) vehicles, characterized by $\mathrm{Ti}, \mathrm{Ba}, \mathrm{Ni}, \mathrm{Cu}, \mathrm{Zn}$ and $\mathrm{Pb}$; (c) road pavement materials, characterized by $\mathrm{Ca}, \mathrm{Si}, \mathrm{Rb}$ and $\mathrm{Sr}$; (d) mixture of marine aerosols and crustal material, characterized by $(\mathrm{Na}, \mathrm{Cl})$ and $(\mathrm{Si}, \mathrm{Mn})$.

\section{Acknowledgements}

The present research was supported by research Grant 9030865 from the City University of Hong Kong.

\section{References}

De Miguel, E., Llamas, J.F., Chacon, E., Berg, T., Larssen, S., Røyset, O., Vadset, M., 1997. Origin and patterns of distribution of trace elements in street dust: unleaded petrol and urban lead. Atmos. Environ. 31, 2733-2740.

Fergusson, J.E., Ryan, D.E., 1984. The elemental composition of street dust from large and small urban areas related to city type, source and particle size. Sci. Total Environ. 34, $101-116$.

Fergusson, J.E., Forbes, E.A., Schroeder, R.J., Ryan, D.E., 1986. The elemental composition and sources of house dust and street dust. Sci. Total Environ. 50, 217-221.

Friedlander, S.K., 1973. Chemical element balances and identification of air pollution sources. Environ. Sci. Technol. 7, 235-240.

Hien, P.D., Binh, N.T., Truong, Y., Ngo, N.T., Sieu, L.N., 2001. Comparative receptor modelling study of TSP, $\mathrm{PM}_{2}$ and $\mathrm{PM}_{2-10}$ in Ho Chi Minh City. Atmos. Environ. 35, 2669-2678.

Kowalczyk, G.S., Choquette, C.E., Gordon, G.E., 1978. Chemical element balances and identification of air pollution sources in Washington, DC. Atmos. Environ. $12,1143-1153$.

Kowalczyk, G.S., Gordon, G.E., Rheingrover, S.W., 1982. Identification of atmospheric particulate sources in Washington, DC, using chemical element balances. Environ. Sci. Technol. 16, 79-90.

Li, X., Poon, C., Liu, P.S., 2001. Heavy metal contamination of urban soils and street dusts in Hong Kong. Appl. Geochem. 16, 1361-1368.

Nicholson, K.W., 1988. A review of particle resuspension. Atmos. Environ. 22, 2639-3651.

Pacyna, J.M., 1986. In: Nriagu, J.O., Davidson, C.I. (Eds.), Toxic Metals in the Atmosphere. Wiley, New York.

Rasmussen, P.E., Subramanian, K.S., Jessiman, B.J., 2001. A multi-element profile of housedust in relation to exterior dust and soils in the city of Ottawa, Canada. Sci. Total Environ. 267, 125-1140.

Schmel, G.A., 1980. Particle resuspension: a review. Environ. Int. 4, 107-127.

Watson, J.G., Chow, J.C., Houck, J.E., 2001. PM 2.5 chemical source profiles for vehicle exhaust, vegetative burning, geological material, and coal burning in Northwestern Colorado during 1995. Chemosphere 43, 1141-1151.

Yu, K.N., Yeung, Z.L.L., Lee, L.Y.L., Stokes, M.J., Kwok, R.C.W., 2002. Determination of multi-element profiles of soil using energy dispersive X-ray fluorescence (EDXRF). Appl. Radiat. Isot. 57, 279-284. 